\title{
PROFIL MISKONSEPSI SISWA KELAS X DI SEBUAH SMA SWASTA DI KARANGANYAR
}

\author{
As Syaffa Al Liina, \\ Dewi Ekaputri Pitorini, \\ Safina Salma, \\ Salis Khoirun Nisa, \\ Baskoro Adi Prayitno \\ Universitas Sebelas Maret \\ E-mail: as.syaffal@student.uns.ac.id
}

\begin{abstract}
Abstrak
Penelitian ini bertujuan untuk mengetahui profil miskonsepsi siswa kelas X di sebuah SMA Swasta di Karanganyar pada materi fotosintesis dan respirasi tumbuhan. Penelitian ini menggunakan metode survei. Populasi penelitian adalah seluruh siswa SMA kelas X MIA. Teknik sampling menggunakan purposive random sampling dengan jumlah sampel sebanyak 25 siswa. Miskonsepsi diukur menggunakan tes pilihan ganda Science \& Plant For School yang disertai Certainty of Response Index (CRI) pada konsep fotosintesis dan respirasi tumbuhan. Analisis data menggunakan analisis deskriptif kuantitatif. Hasil penelitian menunjukkan bahwa persentase siswa yang mengalami miskonsepsi pada konsep Fotosintesis dan Respirasi Tumbuhan sebesar 41,6\%, siswa yang tahu konsep sebesar 38\% dan siswa yang tidak tahu konsep sebesar $20,4 \%$.
\end{abstract}

Kata Kunci: miskonsepsi, Certainty of Response Index (CRI), fotosintesis, respirasi.

\begin{abstract}
This study aims to determine the profile misconception of class $X$ students in a private high school in Karanganyar of photosynthesis and plant respiration material. This study used survey meta-analysis. The study population is all high school students of $\mathrm{X}$ class MIA. The sampling technique uses purposive random sampling with the number of samples as much as 25Student. Misconceptions measured were measured using the Science \& Plant For School multiple-choice test accompanied by the Certainty of Response Index (CRI) on the concept of photosynthesis and plant respiration. Data analysis used quantitative descriptive analysis. The results showed that the percentage of students who experienced misconceptions on the concept of photosynthesis and plant respiration $41.6 \%$, students who know the concept of $38 \%$ and students who do not know the concept of $20.4 \%$.
\end{abstract}

Keywords: misconception, Certainty of Response Index (CRI), photosynthesis, respiration.

\section{PENDAHULUAN}

Biologi merupakan ilmu yang mempelajari berbagai macam aspek kehidupan. Biologi termasuk dalam bagian ilmu sains. Ilmu sains sendiri memiliki karakteristik spesifik yang membedakan dengan ilmu lain. Ilmu sains memiliki karakteristik, yaitu merupakan ilmu pengetahuan kebenarannya telah diujicoba melalui metode ilmiah. Biologi adalah salah satu cabang ilmu pengetahuan alam yang mengkaji konsep-konsep ilmiah mengenai makhluk hidup dan interaksinya. Konsep yang dikaji dalam biologi cukup kompleks untuk dipelajari.

Pembelajaran biologi tidak lepas dari aspek tiga ranah, yaitu kognitif, afektif, dan psikomotorik. Proses pembelajaran biologi lebih sering dituntut untuk lebih memahami serta menghayati suatu konsep baru, mampu menghubungkan konsep baru dengan konsep yang lama untuk dapat mendukung terbangunnya konsep sains yang saling berkaitan. Proses pembelajaran yang demikian sesuai dengan konsep dari kurikulum 2013.

Kesalahan mengkonstruk suatu konsep pengetahuan seringkali menimbulkan kekeliruan pada pemahaman siswa. Miskonsepsi merupakan suatu keadaan dimana terjadi kekeliruan dalam pemahaman suatu konsep pengetahuan akibat beberapa faktor. Di dalam pembelajaran biologi sangat penting untuk memahami setiap konsep pengetahuan yang ada. Konsep pengetahuan merupakan hal dasar untuk merumuskan generalisasi lebih lanjut. Suatu konsep yang dibangun lebih awal akan berpengaruh terhadap pembentukan konsep selanjutnya.

Miskonsepsi merupakan suatu pandangan yang salah terhadap suatu konsep yang dipahami oleh seseorang mengenai konsep yang telah disepakati oleh para ahli. Pengetahuan awal seseorang berpengaruh besar terhadap proses pembelajaran selanjutnya (Suhermiati, Indana, \& Rahayu, 2015). Kesalahan konsep yang terjadi pada siswa 
karena siswa membangun konsep sendiri berdasrkan apa yang dilihat dan didengar (Samiha, Agusta, \& Rolahnoviza, 2015).

Miskonsepsi adalah ketidaksesuaian konsep awal dengan konsep ilmiah. Miskonsepsi adalah keadaan dimana siswa tidak dapat menyerap materi dengan baik (Rahmawati, Prayitno, \& Indrowati, 2013). Penyebab miskonsepsi pada siswa diantaranya adalah berasal dari siswa itu sendiri, guru, buku teks, dan metode pembelajaran yang digunakan oleh guru dalam pembelajaran (Suparno, 2005). Istilah asing dalam biologi serta kerumitan dari suatu konsep dikarenakan kompleksitas informasi atau ciri yang membentuk konsep tersebut juga menyebabkan terjadinya miskonsepsi. Hal lain yang menyebabkan miskonsepsi adalah ketika siswa sedang menemukan pengetahuan dengan cara menerjemahkan pengalaman baru dalam bentuk konsepsi awal(Association, 2013). Pembentukan konsep awal dapat dimulai ketika siswa mendapatkan pengalaman pembelajaran di sekolah maupun dilingkungannya sendiri.

Prakonsepsi siswa pada dasarnya bersifat resisten terhadapperubahan, sehingga apabila prakonsepsi itu salah, miskonsepsi akan sulit dihilangkan dari siswa (Suparno, 2013). Siswa dengan minat yang rendah terhadap mata pelajaran atau materi tertentu cenderung pasif dan mengabaikan konsep baru yang disajikan meskipun berbeda dengan konsep yang selama ini diyakini (Suparno, 2013). Siswa tersebut tidak memperbaiki konsepnya sehingga miskonsepsi tetap melekat pada dirinya.

Miskonsepsi berdampak fatal bagi siswa, artinya siswa selalu merasa benar terhadap apa yang sudah dilihat dan didengar selama proses pembelajaran. Dampak terjadinya miskonsepsi lainnya adalah kegagalan siswa dalam menghubungkan konsep lama dengan konsep yang baru (Pukan \& Marianti, 2017)

Fotosintesis dan respirasi tumbuhan merupakan salah satu konsep yang dikaji dalam biologi. Materi fotosintesis dan respirasi merupakan salah satu konsep dalam biologi yang bersifat abstrak dan memiliki kesulitan yang tinggi, sehingga membingungkan siswa dalam memahaminya (Ariandini, Anggraeni, \& Aryani, 2013b). Materi yang abstrak seringkali menyebabkan miskonsepsi (Sumarni, 2010). Siswa seringkali terjadi salah konsep antara pengertian mendasar tentang respirasi dan fotosintesis. Menurut penelitian Dwi (2013) dalam (Mustaqim, Zulfiani, \& Herlanti, 2014) menyatakan bahwa respirasi tumbuhan terjadi pada malam hari dan tumbuhan dengan daun warna hijau saja yang mengalami fotosintesis.

Masih banyak siswa yang belum paham dan mengerti akan materi yang diajarkan oleh guru dilihat dari masih banyaknya siswa yang belum tuntas pada mata pelajaran sistem komputer, membuat peneliti ingin melakukan penelitian dengan menggunakan metode Certainly of Response Index (CRI). Metode ini menggambarkan bagaimana tingkat kepahaman siswa terhadap mata pelajaran dan menggukur kepercayaan diri siswa dalam menjawab soal. Untuk mengetahui tingkat kepahaman siswa dengan cara memberikan tes atau soal pilihan ganda yang bersifat pemahaman konsep pelajaran, kemudian diukur dengan skala CRI.

Kesulitan yang sering dialami siswa dapat berdampak pada ketidak tercapaiannya hasil belajar siswa secara optimal. Berbagai macam cara dapat digunakan untuk mengidentifikasi miskonsepsi pada siswa. Salah satu cara untuk mengidentifikasi miskonsepsi pada siswa adalah dengan tes diagnostik yang dilengkapi dengan kriteria Certainty of Response Index (CRI). Certainty of Response Index (CRI) merupakan metode yang ditemukan oleh Saleem Hasan yang digunakan untuk mengidentifikasi terjadinya miskonsepsi serta dapat membedakannya dengan tidak tahu konsep dan paham konsep (Mustaqim et al., 2014).

Metode CRI dapat digunakan untuk mengukur tingkat keyakinan atau kepastian responden dalam menjawab setiap soal atau pertanyaan yang diberikan (Hasan, 1999). CRI menentukan tingkat kepastian jawaban siswa berdasarkan pada skala 0-5 (Chaniarosi, 2014). Siswa yang tidak tahu konsep merupakan siswa yang menjawab salah atau benar tetapi meragukan jawabannya. Sedangkan siswa yang paham konsep adalah siswa yang menawab pertanyaaan dengan benar dan yakin akan jawabannya.

Bentuk tes pilihan ganda disertai alasan terbuka untuk melihat alasan yang terdapat pada jawaban siswa. Teknik ini, guru dapat menganalisis pemahaman siswa secara objektif karena selain menjawab soal pilihan ganda dan tingkat keyakinan terhadap jawaban pilihan ganda dapat terungkap sehingga miskonsepsi dapat dengan mudah dan tepat teridentifikasi. Metode yang telah disusun oleh Saleem Hasan memiliki kelemahan yaitu terletak pada pengkategorian tingkatan pemahaman siswa yang memiliki tingkat kepercayaan diri yang rendah serta besarnya faktor menebak siswa dalam menjawab soal karena bentuk soal yang digunakan adalah tes pilihan ganda (Hakim, 2012). Hal ini ditandai dengan adanya siswa yang sebenarnya mampu menjawab dan memahami konsep-konsep yang terdapat pada soal, namun karena memiliki tingkat keyakinan yang rendah menuntunnya memilih skala CRI yang rendah, sehingga dikelompokkan dalam kategori tidak paham konsep/dianggap menebak jawaban (Hakim, 2012).

Berdasarkan hasil temuan penelitian sebelumnya, dapat diketahui bahwa persentase siswa yang mengalami miskonsepsi pada konsep Fotosintesis dan Respirasi Tumbuhan sebesar 37,69\% dan lebih kecil daripada 
persentase siswa yang tidak tahu konsep (Mustaqim et al., 2014). Selain itu pada penelitian sebelumnya diketahui bahwa siswa mengalami miskonsepsi pada konsep produk yang dihasilkan dari proses fotosintesis (Ariandini et al., 2013b).

Berdasarkan uraian di atas, penelitian ini bertujuan untuk mengetahui profil miskonsepsi materi fotosintesis siswa kelas X SMA.

\section{METODE}

Penelitian ini merupakan penelitian deskriptif dengan metode survei. Penelitian dilakukan pada kelas $\mathrm{X}$ di sebuah SMA Swasta di Karanganyar pada 24 Mei 2018. Populasi dalam penelitian ini adalah siswa kelas X MIA yang terdiri 5 kelas dengan rata - rata 25 siswa tiap kelas. Sampel penelitian diambil sejumlah 25 siswa kelas $\mathrm{X}$ MIA 3. Teknik sampling menggunakan purposive random sampling, yaitu teknik pengambilan sumber data dengan pertimbangan tertentu (Januarko \& Setiawati, 2013). Teknik purposive random sampling digunakan karena penentuan subjek penelitian berdasarkan pertimbangan bahwa kelas tersebut bersifat heterogen dan siswa telah memperoleh materi fotosintesis.

Teknik pengumpulan data yang digunakan dalam penelitian ini adalah tes tertulis. Instrumen tes yang digunakan berupa tes pilihan ganda yang disertai dengan Certainty of Response Index (CRI). Tiap butir soal yang digunakan memiliki empat pilihan jawaban. Tes dengan empat pilihan jawaban banyak digunakan karena memungkinkan siswa dapat menerka jawaban sekitar 25\% (Sukardi, 2008). Instrumen tes yang digunakan disusun oleh Griffiths dan Winterbottom (Science \& Plants for School, 2018). Konsep yang diuji pada instrumen tes dapat dilihat pada tabel 1

Tabel 1. Konsep yang diuji

\begin{tabular}{lc}
\hline \multicolumn{1}{c}{ Konsep yang Diuji } & No Soal \\
\hline Menentuka sumber biomassa tanaman & 1 \\
$\begin{array}{l}\text { Mengetahui konsep respirasi dan fotosintesis pada } \\
\text { tanaman di siang hari }\end{array}$ & 2 \\
$\begin{array}{l}\text { Mengetahui konsep respirasi dan fotosintesis pada } \\
\text { tanaman di malam hari }\end{array}$ & 3 \\
Mengetahui fotosintesis pada makhluk hidup & 4 \\
\hline $\begin{array}{l}\text { Mengetahui respirasi pada makhluk hidup } \\
\text { Mengetahui produk fotosintesis }\end{array}$ & 5 \\
$\begin{array}{l}\text { Mengetahui konsep fotosintesis dan respirasi pada } \\
\text { tanaman }\end{array}$ & 6 \\
$\begin{array}{l}\text { Mengetahui fungsi energi cahaya matahari pada } \\
\text { fotosintesis } \\
\text { Membedakan reaksi terang dan reaksi gelap pada } \\
\text { fotosintesis }\end{array}$ & 7 \\
Mengetahui produk fotosintesis pada tanaman air & 9 \\
\hline
\end{tabular}

Data diperoleh dari hasil tes tertulis berupa pilihan ganda disertai indeks CRI berjumlah sepuluh soal. Waktu pengerjaan soal selama 30 menit dengan aturan siswa mengerjakan secara mandiri di kelas dan diawasi oleh peneliti.

Analisis data yang digunakan pada penelitian ini berdasarkan pada jawaban siswa dari tes yang diberikan. Teknik analisis data hasil penelitian melalui empat tahap. Pertama, menentukan kategori tingkatan pemahaman siswa berdasarkan jawaban dan CRI.

Tabel 2. Kategori Tingkatan Pemahaman Siswa berdasarkan CRI

\begin{tabular}{cccc}
\hline Jawaban & Nilai CRI & Deskripsi & Kode \\
\hline Benar & $<2,5$ & Tidak tahu konsep & TTK \\
Salah & $<2,5$ & Tidak tahu konsep & TTK \\
Benar & $>2,5$ & Tahu konsep & TK \\
Salah & $>2,5$ & Miskonsepsi & M
\end{tabular}

Kedua, dilakukan perhitungan persentase jawaban untuk setiap kategori tingkatan pemahaman siswa. Perhitungan persentase menggunakan rumus (Mustaqim et al., 2014):

Keterangan :

$$
P=\frac{f}{N} \times 100 \%
$$

$\mathrm{P}=$ angka persentase kategori $i$

$\mathrm{f}=$ jumlah siswa dengan katagori $i$

$\mathrm{N}=$ jumlah seluruh siswa

Ketiga, dibuat rekapitulasi persentase rata-rata tingkatan pemahaman seluruh siswa. Keempat, dianalisis letak miskonsepsi siswa pada butir soal dengan persentase miskonsepsi siswa tertinggi.

\section{HASIL DAN PEMBAHASAN}

Hasil perhitungan persentase jawaban untuk setiap kategori tingkatan pemahaman siswa disajikan dalam bentuk tabel dan histogram.

Tabel 3. Persentase Tingkatan Pemahaman Siswa

\begin{tabular}{lccccc}
\hline \multicolumn{1}{c}{ Konsep yang Diuji } & No & \multicolumn{3}{c}{ Persentase (\%) } \\
\cline { 3 - 6 } & & Soal & TTK & TK & M \\
\hline $\begin{array}{l}\text { Menentukan } \\
\text { tanaman }\end{array}$ & sumber biomassa & 1 & 28 & 36 & 36 \\
$\begin{array}{l}\text { Mengetahui konsep respirasi dan } \\
\text { fotosintesis pada tanaman di } \\
\text { siang hari }\end{array}$ & 2 & 8 & 20 & 72 \\
$\begin{array}{l}\text { Mengetahui konsep respirasi dan } \\
\text { fotosintesis pada tanaman di }\end{array}$ & 3 & 16 & 68 & 16 \\
malam hari & & & & & \\
Mengetahui fotosintesis pada & 4 & 4 & 96 & 0 \\
makhluk hidup & & & & \\
$\begin{array}{l}\text { Mengetahui respirasi pada } \\
\text { makhluk hidup }\end{array}$ & 5 & 8 & 64 & 28 \\
Mengetahui produk fotosintesis & 6 & 16 & 0 & 84 \\
$\begin{array}{l}\text { Mengetahui konsep fotosintesis } \\
\text { dan respirasi pada tanaman }\end{array}$ & 7 & 28 & 56 & 16
\end{tabular}




\begin{tabular}{lcccc}
\hline \multicolumn{1}{c}{ Konsep yang Diuji } & \begin{tabular}{c} 
No \\
\cline { 2 - 5 }
\end{tabular} & \multicolumn{4}{c}{ Soarsentase (\%) } \\
\cline { 3 - 5 } & TTK & TK & M \\
\hline $\begin{array}{l}\text { Mengetahui fungsi energi cahaya } \\
\text { matahari pada fotosintesis }\end{array}$ & 8 & 40 & 16 & 44 \\
$\begin{array}{l}\text { Membedakan reaksi terang dan } \\
\text { reaksi gelap pada fotosintesis }\end{array}$ & 9 & 32 & 8 & 60 \\
$\begin{array}{l}\text { Mengetahui produk fotosintesis } \\
\text { pada tanaman air }\end{array}$ & 10 & 24 & 16 & 60 \\
Rata-rata & & 20,4 & 38 & 41,6 \\
\hline
\end{tabular}

Keterangan :

$\begin{array}{ll}\text { TTK } & \text { : Tidak Tahu Konsep } \\ \text { TK } & \text { : Tahu Konsep } \\ \text { M } & \text { : Miskonsepsi }\end{array}$

Grafik 1. Persentase Tingkatan Pemahaman Siswa

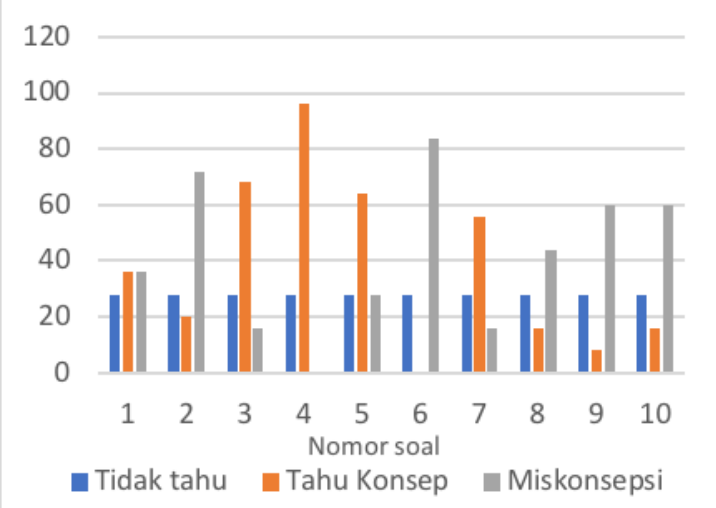

Persentase tingkatan pemahaman siswa paling kecil terletak pada kategori "tidak tahu konsep" dengan rata-rata persentase sebesar $20,4 \%$. Sedangkan rata-rata persentase pada kategori "Tahu Konsep" sebesar 38\%. Persentase tingkatan pemahaman siswa pada konsep fotosintesis dan respirasi tumbuhan di suatu SMA Swasta Karanganyar didominasi pada kategori "miskonsepsi" dengan rata-rata persentase sebesar $41,6 \%$. Miskonsepsi yang dialami siswa disebabkan karena oleh cara belajar siswa yang hanya menghafal suatu konsep tanpa menghubungkan antara konsep yang satu dengan konsep yang lainnya. Miskonsepsi juga dapat disebabkan oleh penalaran siswa yang tidak lengkap atau salah sehingga siswa mengambil kesimpulan yang salah untuk konsep tersebut (Ariandini, Anggraeni, \& Aryani, 2013a).

Grafik 1 menunjukkan bahwa butir soal 2, 6, 8, 9 dan 10 memiliki persentase miskonsepsi lebih tinggi dibandingkan dengan 2 kategori tingkat pemahaman lainnya. Berikut ini adalah pembahasan butir soal 2, 6, 8, 9, dan 10.

1. Butir Soal 2 (konsep respirasi dan fotosintesis pada tanaman di siang hari)

Pertanyaan dan pilihan yang diajukan adalah sebagai berikut :
2. Proses apakah yang terjadi di daun pada siang hari?
a. Respirasi
b. Fotosintesis
c. Fotosintesis dan respirasi
d. Tidak ada jawaban benar

Tanaman melakukan proses fotosintesis dan respirasi pada siang hari. Respirasi seluler terjadi secara terus-menerus pada sel hidup (Levetin \& McMahon, 2008). Siswa mengalami miskonsepsi karena beranggapan bahwa fotosintesis terjadi pada siang hari dan respirasi terjadi pada malam hari.

Menurut Köse (2008), miskonsepsi pada konsep respirasi dan fotosintesis pada tanaman di siang hari dapat terjadi karena siswa beranggapan bahwa repirasi pada tanaman berbeda dengan respirasi pada tumbuhan. Siswa tidak mengetahui bahwa tanaman melakukan respirasi pada siang hari. Miskonsepsi yang terjadi sesuai dengan hasil penelitian Köse (2008) dimana siswa benganggapan bahwa respirasi hanya terjadi pada malam hari.

2. Butir Soal 6 (konsep produk fotosintesis)

Pertanyaan dan pilihan yang diajukan adalah sebagai berikut :

6. Hasil akhir dari proses fotosintesis pada tanaman adalah oksigen dan ...
a. Glukosa
b. Pati
c. Glukosa dan pati
d. Air

Hasil akhir dari proses fotosintesis pada tanaman adalah oksigen, glukosa dan pati. Dua molekul fosfat gliseraldehida adalah perolehan bersih dari enam putaran Siklus Calvin. Molekul fosfat griseraldehida diubah menjadi satu molekul fruktosa1,6-bifosfat yang segera diubah menjadi glukosa. Glukosa yang dihasilkan tidak pernah disimpan tetapi diubah terlebih dahulu menjadi pati, sukrosa atau berbagai produk lainnya (Levetin \& McMahon, 2008). Jawaban yang diberikan siswa menunjukkan bahwa siswa mengalami miskonsepsi. Siswa beranggapan bahwa produk utama dari fotosintesis adalah glukosa.

Hasil penelitian (Ariandini et al., 2013b), menunjukkan bahwa miskonsepsi pada konsep produk fotosintesis merupakan konsep yang paling banyak mengalami miskonsepsi yaitu sekitar $47,05 \%$.

3. Butir Soal 8 (konsep fungsi energi cahaya matahari pada fotosintesis)

Pertanyaan dan pilihan yang diajukan adalah sebagai berikut :

8. Energi cahaya yang ditangkap dalam proses fotosintesis digunakan tanaman untuk sintesis ...

a. Karbohidrat

b. Karbohidrat, asam lemak dan protein

c. Asam lemak dan protein

d. Tidak ada jawaban benar

Sintesis ATP dikenal sebagai fotofosforilasi karena energi yang mendorong seluruh proses berasal 
dari sinar matahari (Levetin \& McMahon, 2008). Fotofosforilasi sangat penting karena selain penggunaan ATP (bersama dengan NADPH) untuk reduksi CO2 pada Siklus Calvin yang menghasilkan karbohidrat, pasokan ATP terus-menerus diperlukan untuk mendukung berbagai kegiatan metabolik lainnya di kloroplas. Kegiatan metabolisme tersebut meliputi biosintesis asam amino, biosintesis asam lemak, biosintesis pati, sintesis protein pada stroma, serta transportasi protein dan metabolit melintasi selaput membran (Hopkins \& Huner, 2008). Jawaban yang diberikan siswa menunjukkan bahwa siswa mengalami miskonsepsi. Siswa beranggapan bahwa semua energi yang ditangkap dalam fotosintesis digunakan untuk mensintesis karbohidrat.

Hasil penelitian (Ariandini et al., 2013b), menunjukkan bahwa miskonsepsi pada konsep produk fotosintesis merupakan konsep yang paling banyak mengalami miskonsepsi yaitu sekitar 47,05\%.

4. Butir Soal 9 (konsep reaksi terang dan reaksi gelap pada fotosintesis)

Pertanyaan dan pilihan yang diajukan adalah sebagai berikut :

9. Fotosintesis terjadi melalui 2 reaksi yang terpisah namun saling berhubungan yaitu reaksi terang dan reaksi gelap. Reaksi gelap fotosintesis terjadi pada saat ...

a. Pada malam hari

b. Pada malam hari dan siang hari

c. Pada siang hari

d. Tidak ada jawaban benar

Fotosintesis terdiri dari dua reaksi utama yaitu reaksi terang dan siklus Calvin. Reaksi terang merupakan fase fotokimia fotosintesis di mana energi radiasi diubah menjadi energi kimia. Selama reaksi terang, terjadi pemecahan molekul air yang melepaskan oksigen dan menyediakan elektron untuk reduksi NADP menjadi NADPH $+\mathrm{H}^{+}$. Reaksi terang juga menyediakan energi untuk sintesis ATP. Reaksi terang memerlukan energi cahaya matahari untuk menghasilkan ATP dan NADPH. Siklus Calvin merupakan fase biokimia yang melibatkann fiksasi dan reduksi $\mathrm{CO}_{2}$ untuk membentuk gula. Siklus Calvin memanfaatkan ATP dan NADPH yang dihasilkan dalam reaksi terang tanpa melibatkan partisipasi langsung cahaya matahari sehingga sering disebut sebagai reaksi gelap (Levetin \& McMahon, 2008). Jawaban yang diberikan siswa menunjukkan bahwa siswa mengalami miskonsepsi. Siswa beranggapan bahwa reaksi gelap hanya terjadi pada malam hari.

Hasil penelitian sebelumnya juga menunjukkan adanya miskonsepsi pada konsep membedakan reaksi terang dan reaksi gelap pada fotosintesis. Siswa mengalami miskonsepsi sebesar 22\% (Ita Viana Dwi \& Erman, 2013)

5. Butir Soal 10 (konsep produk fotosintesis pada tanaman air)

Pertanyaan dan pilihan yang diajukan adalah sebagai berikut :

10. Gelembung udara yang dihasilkan tanaman air di bawah cahaya matahari adalah ...

a. Karbondioksida

b. Oksigen

c. Oksigen ditambah dengan karbondioksida

d. Tidak ada jawaban benar

Jawaban yang diberikan siswa menunjukkan bahwa siswa mengalami miskonsepsi. Siswa beranggapan bahwa gelembung udara yang dihasilkan tanaman air di bawah sinar matahari adalah oksigen murni. Tumbuhan melakukan proses respirasi dan fotosintesis, sehingga gas yang dihasilkan bukan oksigen saja, melainkan gas karbondioksida sebagai hasil respirasi.

Reaksi dalam fotosintesis yang menghasilkan glukosa dan oksigen ialah sebagai berikut : $6 \mathrm{H}_{2} \mathrm{O}+$ $6 \mathrm{CO}_{2}+$ cahaya $\rightarrow \mathrm{C}_{6} \mathrm{H}_{12} \mathrm{O}_{6}$ (glukosa) $+6 \mathrm{O}_{2}$. Secara umum reaksi yang terjadi pada respirasi seluler berkebalikan dengan persamaan di atas. Pada respirasi, gula (glukosa) dan senyawa lain akan bereaksi dengan oksigen untuk menghasilkan karbon dioksida, air, dan energi kimia (Pertamawati, 2010).

Hasil penelitian Rahmatan \& Liliasari (2013), menunjukkan bahwa konsep gas yang dihasilkan tumbuhan mengalami miskonsepsi sebanyak 59,4\%.

\section{PENUTUP}

\section{Simpulan}

Berdasarkan hasil penelitian, dapat diismpulkan bahwa persentase siswa yang mengalami miskonsepsi pada konsep fotosintesis dan respirasi tumbuhan sebesar $41,6 \%$, siswa yang tahu konsep sebesar $38 \%$ dan siswa yang tidak tahu konsep sebesar 20,4\%. Miskonsepsi siswa banyak terjadi pada indikator soal respirasi dan fotosintesis pada tanaman di siang hari, produk fotosintesis, fungsi energi cahaya matahari pada fotosintesis, reaksi terang dan reaksi gelap pada fotosintesis, produk fotosintesis pada tanaman air.

\section{Saran}

Miskonsepsi siswa pada konsep fotosintesis dan respirasi tumbuhan sebesar $41,6 \%$. Miskonsepsi dapat menghambat proses pembelajaran, karena mempengaruhi 
pembentukan konsep siswa selanjutnya. Oleh karena itu guru biologi sebaiknya lebih memperhatikan pemahaman konsep siswa pada materi fotosintesis.

\section{DAFTAR PUSTAKA}

Pertamawati. (2010). Pengaruh Fotosintesis terhadap Pertumbuhan Tanaman Kentang (Solanum tuberosum L.) dalam dalam Lingkungan Fotoautotrof secara In Vitro. Sains Dan Teknologi Indonesia, 12(1).

Pukan, A. N. F. K. K., \& Marianti, A. (2017). Analisis Miskonsepsi Materi Sistem Regulasi pada Siswa Kelas XI SMA Kota Semarang. Journal of Biology Education, 5(024), 3-4.

Rahmatan, H., \& Liliasari. (2013). Pengetahuan Awal Calon Guru Biologi tentang Konsep Katabolisme Karbohidrat (Respirasi Seluler). Jurnal Pendidikan IPA Indonesia, 2(2), 203-208. https://doi.org/10.15294/jpii.v4i2.4179

Rahmawati, Y., Prayitno, B. A., \& Indrowati, M. (2013). Studi Komparasi Tingkat Miskonsepsi Siswa pada Pembelajaran Biologi melalui Model Pembelajaran Konstruktivisme Tipe Novick dan Konstruktivis-Kolaboratif. In Seminar Nasional X
Pendidikan Biologi FKIP UNS.

Samiha, Y. T., Agusta, E., \& Rolahnoviza, G. (2015). Analisis Miskonsepsi Siswa pada Mata Pelajaran IPA di SMPN 4 Penukal Utara Kabupaten Penukal Abab Lematang Ilir Pendopo. Bioilmi, 3(1), 38-46.

Science \& Plants for School. (2018). Photosynthesis Quiz: Test Your Knowledge. Retrieved from http://www.saps.org.uk/secondary/teachingresources/1223-photosynthesis-quiz-test-yourknowledge

Suhermiati, I., Indana, S., \& Rahayu, Y. S. (2015). Analisis Miskonsepsi Siswa pada Materi Pokok Sintesis Protein Ditinjau dari Hasil Belajar Biologi Siswa. Bioedu, 4(3), 985-990.

Sukardi. (2008). Evaluasi Pendidikan Prinsip dan Operasionalnya. Jakarta Timur: PT Bumi Aksara.

Sumarni, W. (2010). Penerapan Learning Cycle Approach sebagai Upaya Meminimalisasi Miskonsepsi Mahasiswa. Jurnal Penelitian Pendidikan (JPP), 27(2).

Suparno, P. (2005). Miskonsepsi dan Perubahan Konsep dalam Pendidikan Fisika. Jakarta: PT Grasindo. 